\title{
The haematophagous feeding stage of anadromous populations of sea lamprey Petromyzon marinus: low host selectivity and wide range of habitats
}

Sergio Silva ${ }^{1,2, *}$; Mário J. Araújo ${ }^{3}$; Miguel $\mathrm{Bao}^{4}$; Gonzalo Mucientes ${ }^{5,6}$ \& Fernando $\mathrm{Cobo}^{1,2}$

${ }^{1}$ Department of Zoology and Physical Anthropology, Faculty of Biology, University of Santiago de Compostela, Lope Gómez de Marzoa s/n, 15782 Santiago de Compostela, Spain.

${ }^{2}$ Hydrobiology Station "Encoro do Con”, Castroagudín s/n, 36617 Vilagarcía de Arousa, Pontevedra, Spain.

${ }^{3}$ CIMAR-LA/CIIMAR Interdisciplinary Centre of Marine and Environmental Research, Rua dos Bragas, 289, 4050-123 Porto, Portugal

${ }^{4}$ ECOBIOMAR, Instituto de Investigaciones Marinas (CSIC), Eduardo Cabello 6, 36208 Vigo, Spain

${ }^{5}$ Grupo de Ecología Pesquera, Instituto de Investigaciones Marinas (CSIC), Eduardo Cabello 6, 36208 Vigo, Spain.

${ }^{6}$ CIBIO - Universidade de Porto, Centro de Investigação em Biodiversidade e Recursos Genéticos, Campus Agrário de Vairão, 4485-668 Vairão, Portugal. 
Abstract Limited information is available regarding habitat use and host species of the haematophagous feeding stage of the anadromous sea lamprey Petromyzon marinus Linnaeus, 1758, due to the difficulties in capturing feeding lampreys and wounded hosts. The aim of this study is to provide new records of $P$. marinus feeding on host species and to review the available information in this regard to better know the ecology and distribution of sea lamprey during this stage. Thus, new records of $P$. marinus individuals or wounds on 23 species of fishes and cetaceans are provided. Nineteen of these species were described for the first time as hosts of $P$. marinus. As a result, an updated list of 54 host species is provided. They belong to diverse taxonomic groups and exhibit different morphological, physiological and ecological patterns. The attacks were located from fresh and brackish waters to open sea. The results suggest that the marine distribution of $P$. marinus is mainly related to coastal areas with part of the population widely dispersed in offshore areas. This remarkable capacity of inhabiting a broad range of aquatic ecosystems and exploiting different host species could have favoured the dispersal ability and evolutionary success of sea lamprey.

Keywords: Parasite-host interaction; distribution; trophic ecology; North Atlantic Ocean; fisheries; sea.

*Author to whom correspondence should be addressed. Tel.: 0034981563100 Ext. 13282; e-mail: sergio.silva@usc.es 


\section{Introduction}

The sea lamprey Petromyzon marinus Linnaeus, 1758 is typically an anadromous species that spends the larval stages in streams and the adult-feeding stages in open sea waters. The larvae burrow in fine sediment and feed by filtration (Quintella et al., 2003). After metamorphosis, the juveniles migrate to the sea and begin feeding on blood and fluids of several species of Chondrichthyes, Osteichthyes and cetaceans (Beamish, 1980; Halliday, 1991; Kelly \& King, 2001). In some cases, as in the Upper Laurentian Great Lakes of North America, postmetamorphic individuals can also complete the haematophagous feeding stage without migrating to the sea (Bergstedt \& Swink, 1995); yet, even within rivers inside their natural range, evidence is increasing that haematophagous feeding can begin in freshwater (Silva et al., 2013b; c). After one to two years of haematophagous feeding (Halliday, 1991; Silva et al., 2013a) sea lamprey adults return to fresh water to spawn and die.

The freshwater phase of the $P$. marinus life cycle is well known, but as for the other anadromous lamprey species, very little information has been gathered during the oceanic phase (Renaud et al., 2009; Lança et al., 2013). Thus, due to inherent

difficulties for capturing adult sea lampreys in the sea, available information is restricted to occasional captures of some species with wounds caused by P. marinus or, in some cases, with the lamprey attached (Halliday, 1991; Hardisty, 2006; Lança et al., 2013).

So far, most detailed studies on the haematophagous phase of $P$. marinus have been made for the landlocked populations of the Great Lakes of North America (Clemens et 
al., 2010). This is because the non-native landlocked form is considered a pest due to the high economic impact in terms of damage to fish stocks and the resultant expenditure of large sums of money on its control (Hardisty, 2006). Nonetheless, studies on the haematophagous stage of native anadromous $P$. marinus populations, threatened and economically important in some regions, have been increasing during recent years (Clemens et al., 2010). Therefore, the aim of this paper is to provide new findings on $P$. marinus host species obtained from several sources and in different aquatic habitats, as well as to review the available information on this regard in order to better know the ecology and distribution of sea lamprey during this stage.

\section{Materials and methods}

New records of $P$. marinus feeding on host species were obtained from inland and coastal commercial fisheries; inland and marine sport fishing; offshore surveys (scientific expeditions and mark-recapture campaigns); stranded individuals and personal communications from other researchers. The presence of wounds caused by $P$. marinus in those species was determined following King \& Edsall (1979) and Ebener et al. (2006) and wounds were sorted into pierced (indicative of active feeding) and nonpierced wounds (cannot confirm active feeding) (Silva et al., 2013c).

Species captured with wounds caused by $P$. marinus were obtained from commercial fisheries (trammels and seines) operating off the NW Iberian Peninsula in 2012 and 2013 as well as one record from sport marine fishing in 2008 (Fig. 1). In adidition, information on species with sea lamprey wounds collected by monitoring surveys of 
UTPB/Sp (Technical Unity of Coastal Fishing) during 2005 and 2006 was also included.

Data on sea lamprey hosts were also generated from a scientific expedition on the research vessel Vizconde de Eza in international waters of the Grand Banks of Newfoundland, in NAFO (Northwest Atlantic Fisheries Organization) regulatory areas 3N, 3O, 3L and $3 \mathrm{M}\left(43-48^{\circ} \mathrm{N}\right.$; 46-52 $\mathrm{W}$; Fig. 1) from June to August 2013 (GonzálezCostas et al., 2013). Important fisheries for the European fishing fleet are located in this region (García-Orellán, 2010). Information from a mark-recapture campaign of pelagic sharks captured by surface longline in the North West Atlantic $\left(42^{\circ} \mathrm{N} ; 45^{\circ} \mathrm{W}\right.$; Fig. 1$)$ in 2009 and 2010 was also used. This study area is located in a very productive zone due to the confluence of the warm Gulf Stream and the cold Labrador Current (Hurrell et al., 2003).

Information on sea lamprey attachment and feeding was also obtained from four species of stranded cetaceans in the NW Iberian Peninsula. This information was collected from 2005 to 2013 by the CEMMA association (Coordinadora para o Estudio dos Mamíferos Mariños) and CEPESMA (Coordinadora para el Estudio y Protección de las Especies Marinas).

A species captured with postmetamorphic $P$. marinus still attached or wounds caused by them was obtained from commercial fishing in the River Miño estuary (NW Iberian Peninsula; Fig. 1). Several anadromous and euryhaline species are captured in this river mainly by trammel nets (BOPDEPO, 2013). Dr. John B. Hume provided information on newly metamorphosed $P$. marinus feeding on freshwater fish species in Lake Derg 
(River Shannon, Ireland). The host individuals were collected by sport fishing between 2006 and 2012. Dr. Richard Sabatié provided information on host species of P. marinus observed in the French Brittany region (rivers, estuaries and coastal zone).

\section{Results}

In total, 27 new records of attachments of $P$. marinus on 23 different species are provided (Table 1), comprising two species of Chondrichthyes, 17 of Osteichthyes and four cetaceans belonging to 13 orders and 21 different families. These belong to two orders and two families of Chondrichthyes, 10 orders and 15 families of Osteichthyes, and four families of cetaceans belonging to the order Cetartiodactyla. Regarding the species ecology, 16 of them are marine, four are freshwater species and three are diadromous (Tables 1-2). Of these, $48 \%$ (11 of 23) are demersal and 52\% are pelagic (Tables 1-2). All individuals showed pierced wounds (indicative of active feeding) with exception of Reinhardtius hippoglossoides (Walbaum, 1792).

Records are provided from fresh, brackish and marine waters (Table 1, Fig. 1). All host species from the coastal marine areas were captured up to $40 \mathrm{~km}$ from the coast. In that area, the species Myliobatis aquila (Linnaeus, 1758), Belone belone (Linnaeus, 1761) and Merluccius merluccius (Linnaeus, 1758) (the individual captured in 2007) were captured with a sea lamprey (total length of 20,22 and $23 \mathrm{~cm}$ respectively) still attached to them. Moreover, a postmetamorphic sea lamprey (total length of $32.5 \mathrm{~cm}$ and weight of $65.8 \mathrm{~g}$ ) was captured feeding on Alosa alosa (Linnaeus, 1758) (the individual captured in 2014) in the river Miño estuary. Coastal fishermen from the NW Iberian Peninsula confirmed that captures of $P$. marinus (both adults and newly transformed) as 
by-catch occur sporadically in this region with the main capture period situated between January and April.

Host species of $P$. marinus obtained in offshore surveys, Sebastes mentella Travin, 1951, Anarhinchas lupus Linnaeus, 1758 and $R$. hippoglossoides (Table 1) were caught by bottom trawl 430, 490 and $400 \mathrm{~km}$ from the nearest coast (Newfoundland) and at 200, 300 and $900 \mathrm{~m}$ deep respectively. Blue shark Prionace glauca (Linnaeus, 1758) was caught in two consecutive years with a sea lamprey still attached (Online Resource 1) $815 \mathrm{~km}$ from the nearest coast (Newfoundland).

On fusiform bony fishes, $P$. marinus wounds consistently occurred below the lateral line and usually close to the pectoral fins (Fig. 2). By contrast, $P$. marinus sucker marks on flatfish, sharks and cetaceans were spread along the lateral or dorsal regions (Fig. 3; Online Resource 1). Non-pierced scars were observed on different parts of the body of P. glauca, Balaenoptera acutorostrata Lacépède, 1804 and Mesoplodon bidens (Sowerby, 1804), which appeared to have been caused by drag and displacement of $P$. marinus (Fig. 3).

Following combination of our new records with a detailed review of the existing literature-based records, an updated list of host species described for anadromous $P$. marinus in its native range is presented (Table 2). A total of 54 confirmed host species: 6 chondrichthyans, 38 osteichthyans, and 10 cetaceans belonging to 12 orders and 28 different families are now listed. Moreover, in five species, non-pierced wounds were observed, so active feeding was not confirmed (Table 2). As shown in Table 3, fifty six percent of confirmed host species are at least near threatened, and $9 \%$ were not 
evaluated or current data are deficient. They also exhibit diverse distribution ranges and migratory patterns (Table 3). Most host species (91\%) are carnivorous or planktivorous. Fifty two percent of host species were pelagic, and the $48 \%$ were demersal (Table 3 ).

\section{Discussion}

This study confirms the haematophagous feeding of anadromous $P$. marinus on 23 host species, 19 of which had not been described before as part of the diet of P. marinus (Table 1). These species are included in one superorder, five orders, and twelve families which were not referred as hosts of anadromous sea lampreys so far: $M$. aquila is the first species of superorder Batoidea; Esox lucius Linnaeus, 1758 is the first species of order Esociformes; Solea solea (Linnaeus, 1758) and $R$. hippoglossoides are the first species of the order Pleuronectiformes; S. mentella is the first species of order Scorpaeniformes; B. belone of order Beloniformes; M. merluccius of family Merluccidae; Trichiurus lepturus Linnaeus, 1758 of family Trichiuridae; Trachurus trachurus (Linnaeus, 1758) of family Carangidae; A. lupus of the family Anarhichadidae; Boops boops (Linnaeus, 1758) of family Sparidae; and finally Physeter macrocephalus Linnaeus, 1758 is the first record in the family Physeteridae. In the case of $P$. glauca, the presence of $P$. marinus attached to this species was described earlier by Benz \& Bullard (2004); nonetheless, the active feeding on this species only now is confirmed.

The records of several demersal host species (Table 3) are in accordance with findings provided by Lança et al. (2013) from muscle fatty acid analysis of adult P. marinus, which point to the important role of these species in the diet of anadromous sea lamprey 
populations, at least during their marine stage. Besides, several demersal species have also been described by Orlov et al. (2009) as an important part of Pacific lamprey Entosphenus tridentatus (Richardson, 1836) diet. Pacific lamprey and sea lamprey are rather similar in their ecology, in that they both range widely during their parasitic phase (Kelly \& King, 2001; Orlov et al., 2008; Clemens et al., 2010).

The ecological, morphological, physiological and taxonomical differences among host species of $P$. marinus are in accordance with a low degree of host selection as previously suggested by Silva et al. (2013c) for anadromous populations and by Hardisty \& Potter (1971) and Bence et al. (2003) for landlocked populations. Indeed, the main selection factor seems to be the host size with larger individuals or species being the preferred hosts (Bence et al., 2003). Therefore, larger hosts provide to $P$. marinus a more nutritional feeding during more time (Farmer, 1980; Hardisty, 2006). Some small hosts were described for newly transformed P. marinus in freshwater (Araújo et al., 2013a; Silva et al., 2013b, c). However, as the haematophagous phase progresses, lampreys increase their size and consumption rate (Farmer, 1980). As a consequence, it has been suggested that they tend to progressively move away from the river of origin to the sea looking for larger hosts (Holčík, 1986; Halliday, 1991).

Kelly \& King (2001) based on earlier works of Beamish (1980) and Farmer (1980) reported a total of 12 host species of $P$. marinus. But Lança et al. (2013) listed a total of 30 host species of $P$. marinus at sea, and this paper has increased that list to a total of 54 confirmed and five nonconfirmed host species from different taxonomic groups in fresh water, marine and brackish habitats within the natural range of $P$. marinus. The low 
selectivity of sea lamprey suggests that they could also feed on these non-confirmed host species.

Most listed host species are present along P. marinus' distribution range (Froese \& Pauly, 2011; Renaud, 2011) and for sea lamprey as well; most of them are or were targeted by fishing activity (Froese \& Pauly, 2011; IUCN, 2013). As a result of overfishing and other factors, populations of targeted fishes have been declining over decades (Pauly et al., 1998; Jackson et al., 2001). Although the role of targeted species in the diet of $P$. marinus may be overestimated because fisheries are often the source of information, this decline may directly affect populations of anadromous sea lamprey as host abundance can be the principal factor in predicting adult lamprey returns to the rivers (Murauskas et al., 2013).

This paper also records haematophagous feeding of $P$. marinus in freshwater in Ireland and in French Britanny (Table 1). Such evidence, together with recent observations in Iberian Peninsula streams (Araújo et al., 2013a; Silva et al., 2013b; c) and previously in North America (Beamish, 1980; Powell et al., 1999), suggest that freshwater feeding by early postmetamorphic sea lamprey is a widespread behaviour in anadromous populations of $P$. marinus in their native range. Feeding on exotic species was confirmed with the observation of $P$. marinus feeding on E. lucius in the Lake Derg. Both the freshwater feeding and the ability of feeding on exotic species have also been described for other anadromous species as European river lamprey Lampetra fluviatilis (Linnaeus, 1758) (Inger et al., 2010; Hume et al., 2013). 
The downstream migration of $P$. marinus usually occurs between autumn and spring (Beamish, 1980; Kelly \& King, 2001; Silva et al., 2013b) and partially overlaps with upstream migration of spawners, which takes place between winter and spring (Quintella et al., 2004; Hardisty, 2006; Cobo et al., 2010; Araújo et al., 2013b). Thus, both in East and West Atlantic (Beamish, 1980; Halliday, 1991; Dempson \& Porter, 1993; Powell et al., 1999; Igoe et al., 2004; this paper) catches or observations of parasitic-phase sea lampreys in rivers, estuaries and coastal areas occur more often from autumn to spring and for the newly transformed individuals of small size or individuals of adult size. By contrast, records in more remote areas occur mainly in summer and for lampreys of medium size. This is in accordance with the suggested short duration of the haematophagous stage of $P$. marinus of close to one year, as recently described by Silva et al. (2013a).

Several $P$. marinus have been caught up to $350-450 \mathrm{~km}$ away from the nearest coast (Lelek, 1973; Dempson \& Porter, 1993; Kelly \& King, 2001) and at up to 985-1000 m deep (Hardisty \& Potter, 1971; Beamish, 1980). Also, the occurrence of sea lampreys feeding in Icelandic waters has been reported (Pereira et al., 2012; Ólafsdóttir \& Shinn, 2013), the rivers in which the existence of reproduction or larval populations of $P$. marinus has not been described so far (Pereira et al., 2012). Haedrich (1977) reported a bottom trawl-caught specimen at $4099 \mathrm{~m}$ deep, $400 \mathrm{~km}$ off southern New England, but acknowledged the possibility that capture occurred in midwater upon net retrieval. Our results (captures at up to $815 \mathrm{~km}$ from the nearest coast) confirm that at least part of the sea lamprey population can be widely dispersed at sea. In addition, some listed host species are oceanodromous, and they present wide habitat ranges reaching deep waters and areas located far from the coast as is the case with P. glauca, Scomber scombrus 
Linnaeus, 1758, Urophycis chuss (Walbaum, 1792), M. merluccius, T. trachurus, S. mentella, Grampus griseus (Cuvier, 1812) and P. macrocephalus that can reach $1000 \mathrm{~m}$ depth (Froese \& Pauly, 2011; IUCN, 2013). In the case of C. maximus, Somniosus microcephalus (Bloch \& Schneider, 1801) and R. hippoglossoides, their habitats at depths greater than $2000 \mathrm{~m}$ are reported (Froese \& Pauly, 2011).

Nonetheless, several factors suggest that $P$. marinus distribution range at sea is partially restricted. Silva et al. (2013a) showed that $P$. marinus can reach the adult size in approximately 1 year of haematophagous feeding. Moreover, part of the postmetamorphic population can spend several months, feeding in rivers and estuaries, before migrating to sea (Silva et al., 2013b, c). Genetic differences suggest that little exchange of individuals exists between European and North American sea lamprey populations (Rodríguez-Muñoz et al., 2004; Genner et al., 2012); although some individuals may cross the Atlantic Ocean attached to their hosts, it will, therefore, not be a common pattern. Petromyzon marinus as well as E. tridentatus do not home to natal streams (Waldman et al., 2008; Spice et al., 2012). They are widely dispersed at sea, and then they look for suitable spawning streams based on different factors as the presence of larval pheromones (Meckley et al., 2014). However, the genetic differences recorded by Spice et al. (2012) for E. tridentatus between locations, which are inconsistent with philopatry, show also the absence of panmixia, which those authors consider as being due to a limited dispersal at sea.

Besides, most catches and observations of $P$. marinus have occurred in coastal and shallow regions, corresponding to the continental slope and shelf area (Beamish, 1980; Halliday, 1991; Dempson \& Porter, 1993; Hardisty, 2006) as also described for $E$. 
tridentatus (Orlov et al., 2008, 2009). Thus, Orlov et al. (2008) provide catches of $E$. tridentatus widely dispersed at sea and at depths up to $1485 \mathrm{~m}$ but with over $80 \%$ of individuals captured at depths less than $500 \mathrm{~m}$ when using bottom trawls and less than $200 \mathrm{~m}$ in pelagic surveys. Therefore, as also suggested by Lança et al. (2013) marine distribution of $P$. marinus seems to occur mainly in the continental shelf and slope regions until the mesopelagic level, with a small part of the population reaching more remote areas. Distribution of anadromous lampreys at sea seems to be linked to the abundance of hosts and their mobility (Johnson \& Anderson, 1980; Orlov et al., 2008; Lança et al., 2013; Murauskas et al., 2013). Individuals attached to large hosts with wide dispersion patterns could get constant and highly nutritive food but that strategy could also increase the risk of not returning to fresh waters to reproduce (Lança et al., 2013).

Finally, related to the selection of feeding sites on the host body by P. marinus, our data in accordance with previous findings have shown a preference for feeding under the lateral line and in the vicinity of the pectoral fin for most host species (Farmer \& Beamish, 1973; Beamish, 1980; Cochran, 1986), and preference for the dorsal and lateral regions for flatfishes, cetaceans and some shark species (Nichols \& Hamilton, 2004; Wilkie et al., 2004; Nichols \& Tscherter, 2011; Samarra et al., 2012; Ólafsdóttir \& Shinn, 2013). It seems to be related to a thinner muscular layer, less dense scaling and the presence of relatively large blood vessels (Farmer \& Beamish, 1973; Farmer, 1980; Cochran \& Lyons, 2010; Nichols \& Tscherter, 2011). Besides, in larger host species as cetaceans, it seems to be related also to areas exposed to low water flows (Nichols \& Tscherter, 2011). These preferences appear to combine low costs in terms of 
handling time before feeding with greater rates of energy intake once feeding has been initiated (Farmer, 1980; Cochran, 1986).

The great number of non-pierced wounds in cetaceans and chondrichthyans might be caused by the search of sea lamprey for more suitable feeding areas (Nichols \& Tscherter, 2011). Related to the ability of $P$. marinus to feed on sharks (urea-rich species), Wilkie et al. (2004) confirmed the ability of sea lamprey to penetrate the dermal denticle armour of sharks, to rapidly excrete large volumes of urea and a high capacity to deaminate amino acids. These authors concluded that these abilities may represent adaptations that have contributed to the evolutionary success of lampreys.

In conclusion, this study demonstrates that in its natural range, the haematophagous feeding stage of $P$. marinus exhibits a low selectivity of host species, as shown for landlocked populations and a wide range of habitats (from rivers and estuaries to coastal and offshore areas) that they can use during this stage. This plasticity in the haematophagous stage related to habitat and host species could have favoured the dispersal ability and evolutionary success of sea lamprey. 


\section{Acknowledgments}

The authors thank the staff of the Hydrobiology Station "Encoro do Con" (USC), Dr. Carlos Antunes (CIIMAR-UP), Dr. John B. Hume (University of Glasgow), Dr. Richard Sabatié (ENSAR-FR, Fig. 2b-c), Dr. Rodrigo López (PAISASIGMO, Fig. 1), Rafael Bañon (UTPB-Xunta de Galicia), Manuel E. Garci (IIM-CSIC), CEMMA (Fig. 3a-d), CEPESMA, scientific crew of Vizconde de Eza Oceanographic Vessel, commercial vessels "Ameal" and "Amel”, Skipper A. Blanco ("Casca", Bueu), Skipper P. Castro (MERAK, Galicia), João Araújo and Napoleão Rodrigues (fishermen of River Minho), Vasco Presa (fisherman of V. P. Âncora) and Xulio Valeiras (IEO; Fig. 2e) for their important collaboration and for providing new records of host species of anadromous sea lamprey. The authors are also grateful to Dr. Martyn C. Lucas (University of Durham) for his valuable comments. This study has been partially supported by the project 10PXIB2111059PR of Xunta de Galicia and the project MIGRANET of the Interreg IV B SUDOE (South-West Europe) Territorial Cooperation Programme (SOE2/P2/E288). The authors are also grateful to two anonymous referees for their helpful comments. 


\section{References}

Araújo, M. J., D. Novais \& C. Antunes, 2013a. Record of a newly metamorphosed anadromous sea lamprey (Petromyzon marinus Linnaeus, 1758) feeding on a freshwater fish. Journal of Applied Ichthyology 29: 1380-1381.

Araújo, M. J., R. O. A. Ozório, R. J. B. Bessa, A. Kijjoa, J. F. M. Gonçalves \& C. Antunes, 2013b. Nutritional status of adult sea lamprey (Petromyzon marinus Linnaeus, 1758) during spawning migration in the Minho River, NW Iberian Peninsula. Journal of Applied Ichthyology 29: 808-814.

Beamish, F. W. H., 1980. Biology of the North American anadromous sea lamprey, Petromyzon marinus. Canadian Journal of Fisheries and Aquatic Sciences 37: 1924-1943.

Bence, J. R., R. A. Bergstedt, G. C. Christie, P. A. Cochran, M. P. Ebener, J. F. Koonce, M. A. Rutter \& W. D. Swink, 2003. Sea lamprey (Petromyzon marinus) parasite host interactions in the Great Lakes. Journal of Great Lakes Research 29: 253282.

Benz, G. \& S. A. Bullard, 2004. Metazoan parasites and associates of chondrichthyans with emphasis on taxa harmful to captive hosts. In: Smith M., D. Warmolts, D. Thoney \& R. Hueter (eds), The Elasmobranch Husbandry Manual: Captive Care Of Sharks, Rays, And Their Relatives. Ohio Biological Survey, Columbus, OH: $325-416$. 
Bergstedt, R. A. \& W. D. Swink, 1995. Seasonal growth and duration of the parasitic life stage of landlocked sea lampreys (Petromyzon marinus). Canadian Journal of Fisheries and Aquatic Sciences 52: 1257-1264.

BOPDEPO, 2013. Boletín oficial provincia de Pontevedra, No 152. Deputación de Pontevedra.http://www.bop.depo.es/bop.PONTEVEDRA/2013/bop.PONTEVE DRA.20130809.152.pdf. Accessed 9 August 2013.

Clemens, B. J., T. R. Binder, M. F. Docker, M. L. Moser \& S. A. Sower, 2010. Similarities, differences, and unknowns in biology and management of three parasitic lampreys of North America. Fisheries 35: 580-594.

Cobo, F., S. Silva, R. Vieira-Lanero, M. J. Servia, J. Sánchez-Hernández, S. Barca, S. Rivas, M. Couto, P. Gómez, D. J. Nachón, C. Morquecho, L. Lago, M. C. Cobo, 2010. Estado de conservación das poboacións de lamprea mariña en ríos de Galicia. Xunta de Galicia, Consellería do Medio Rural, Dirección Xeral de Conservation da Natureza, Santiago de Compostela.

Cochran, P. A., 1986. Attachment sites of parasitic lampreys: comparisons among species. Environmental Biology of Fishes 17: 71-79.

Cochran, P. A. \& J. Lyons, 2010. Attachments by parasitic lampreys within the branchial cavities of their hosts. Environmental Biology of Fishes 88: 343-348.

Dempson, J. B. \& T. R. Porter, 1993. Occurrence of sea lamprey, Petromyzon marinus, in a Newfoundland river, with additional records from the northwest Atlantic. Canadian Journal of Fisheries and Aquatic Sciences 50: 1265-1269. 
Ebener, M. P., E. L. King Jr \& T. A. Edsall, 2006. Application of a dichotomous key to the classification of sea lamprey marks on Great Lakes fish. Great Lakes Fish Com Misc Publ. http://www.glfc.org/pubs/SpecialPubs/2006-02.pdf. Accessed 9 August 2013.

Farmer, G. J., 1980. Biology and physiology of feeding in adult lampreys. Canadian Journal of Fisheries and Aquatic Sciences 37: 1751-1761.

Farmer, G. J. \& F. W. H. Beamish, 1973. Sea lamprey (Petromyzon marinus) predation on freshwater teleosts. Journal of the Fisheries Research Board of Canada 30: 601-605.

Froese, R. \& D. Pauly (eds), 2011. FishBase version 12/2013. World Wide Web electronic publication. http://www.fishbase.org. Accessed 10 August 2013.

Gallant, J., C. Harvey-Clark, R. A. Myers \& M. J. W. Stokesbury, 2006. Sea lamprey attached to a Greenland Shark in the St. Lawrence Estuary, Canada. Northeastern Naturalist 13: 35-38.

García-Orellán, R., 2010. Terranova: the Spanish cod fishery on the Grand Banks of New-Foundland in the twentieth century. BrownWalker Press, Boca Raton.

Genner, M. J., R. Hillman, M. McHugh, S. J. Hawkins, M. C. Lucas, 2012. Contrasting demographic histories of European and North American sea lamprey (Petromyzon marinus) populations inferred from mitochondrial DNA sequence variation. Marine \& Freshwater Research 63: 827-833.

González-Costas, F., D. González-Troncoso, G. Ramilo, E. Román, J. Lorenzo, M. Casas, C. Gonzalez, A. Vázquez \& M. Sacau, 2013. Scientific Council meeting - 
June 2013, Spanish Research Report for 2012, NAFO SCS Doc. 13/07 - Serial No N6150. http://digital.csic.es/bitstream/10261/86585/1/scs13-07.pdf. Accessed 9 August 2013.

Haedrich, R. C., 1977. A sea lamprey from the deep. Copeia 4: 767-8.

Halliday, R. G., 1991. Marine distribution of the sea lamprey (Petromyzon marinus) in the northwest Atlantic. Canadian Journal of Fisheries and Aquatic Sciences 48: $832-842$.

Hardisty, M. W., 1986. Petromyzon marinus (Linnaeus 1758). In: Holčík J. (ed) The freshwater fishes of Europe, Vol 1 Part 1 - Petromyzontiformes. Aula-Verlag, Wiesbaden: 94-116.

Hardisty, M. W., 2006. Lampreys: Life without Jaws. Forrest Text, Ceredigion.

Hardisty, M. W. \& I. C. Potter, 1971. The general biology of adult lampreys. In Hardisty, M. W. \& I. C. Potter (eds), The Biology of Lampreys, Vol. 1. Academic Press, London: 127-206.

Heyning, J. E., 2003. Cuvier's Beaked Whale (Ziphius cavirostris). In: Perrin W. F., B. Würsig, J. G. M. Thewissen (eds), Encyclopedia of Marine Mammal. Academic Press, San Diego, CA: 305-307.

Holčík, J., 1986. The freshwater fishes of Europe, Vol. 1 Part I - Petromyzontiformes. Aula-Verlag, Wiesbaden.

Hume, J. B., C. E. Adams, C. W. Bean \& P. E. Maitland, 2013. Evidence of a recent decline in lampreys parasitism of a nationally rare whitefish Coregonus 
clupeoides in Loch Lomond, Scotland: is there a diamond in the ruffe? Journal of Fish Biology 82: 1708-1716.

Hurrell, J. W., Y. Kushnir, G. Ottersen \& M. Visbeck, 2003. The North Atlantic Oscillation: climatic significance and environmental impact. Geophysical Monograph Series. DOI: 10.1029/GM134.

Igoe, F., D. T. G. Quigley, F. Marnell, E. Meskell, W. O’Connor \& C. Byrne, 2004. The sea lamprey Petromyzon marinus (L.), river lamprey Lampetra fluviatilis (L.) and brook lamprey Lampetra planeri (Bloch) in Ireland: General biology, ecology, distribution and status with recommendations for conservation. Proceedings of the Royal Irish Academy, Section B, 104: 43-56.

Inger, R., R. A. McDonald, D. Rogowski, A. L. Jackson, A. Parnell, S. J. Preston, C. Harrod, C. Goodwin, D. Griffiths, J. T. A. Dick, R. W. Elwood, J. Newton \& S. Bearhop, 2010. Do non-native invasive fish support elevated lamprey populations? Journal of Applied Ecology 47: 121-129.

IUCN, 2013. IUCN Red List of Threatened Species. Version 2013.2. http://www.iucnredlist.org. Accessed 20 December 2013.

Jackson, J. B. C., M. X. Kirby, W. H. Berger, K. A. Bjorndal, L. W. Botsford, B. J. Bourque, R. H. Bradbury, R. Cooke, J. Erlandson, J. A. Estes, T. P. Hughes, S. Kidwell, C. B. Lange, H. S. Lenihan, J. M. Pandolfi, C. H. Peterson, R. S. Steneck, M. J. Tegner \& R. R. Warner, 2001. Historical overfishing and the recent collapse of coastal ecosystems. Science 293: 629-638. 
Japha, A., 1910. Further contributions to the knowledge of whale skin. Zoologische Jahrbuecher 12: 711-718.

Jensen, C. \& F. J. Schwartz, 1994. Atlantic Ocean occurrences of the sea lamprey, Petromyzon marinus (Petromyzontiformes, Petromyzontidae), parasitizing sandbar, Carcharhinus plumbeus, and dusky, C. obscurus (Carcharhiniformes: Carcharhinidae), sharks off North and South Carolina. Brimleyana 21: 69-72.

Jensen, C., F. J. Schwartz \& G. Hopkins, 1998. A sea lamprey (Petromyzon marinus)tiger shark (Galeocerdo cuvier) parasitic relationship off North Carolina. Journal of the Elisha Mitchell Scientific Society 114: 72-73.

Johnson, B. G. H. \& W. C. Anderson, 1980. Predatory-phase sea lampreys (Petromyzon marinus) in the Great Lakes. Canadian Journal of Fisheries and Aquatic Sciences 37: 2007-2020.

Kelly, F. L. \& J. J. King, 2001. A review of the ecology and distribution of three lamprey species, Lampetra fluviatilis (L.), Lampetra planeri (Bloch) and Petromyzon marinus (L.): a context for conservation and biodiversity considerations in Ireland. Biology and Environment: Proceedings of the Royal Irish Academy 101B: 165-185.

King Jr, E. L. \& T. A. Edsall, 1979. Illustrated field guide for the classification of sea lamprey attack marks on great lakes lake trout. Great Lakes Fishery Commission - Special Publication, 79-1.

Lança, M. J., M. Machado, R. Ferreira, I. Alves-Pereira, B. R. Quintella \& P. R. Almeida, 2013. Feeding strategy assessment through fatty acid profiles in 
muscles of adult sea lampreys from the western Iberian coast. Scientia Marina 77: 281-291.

Lelek, A., 1973. Occurrence of the sea lamprey in midwater off Europe. Copeia 1: 136137.

Mansueti, J., 1962. Distribution of small, newly metamorphosed sea lampreys, Petromyzon marinus, and their parasitism on menhaden, Brevoortia tyrannus, in mid-Chesapeake Bay during winter months. Chesapeake Science 3: 137-139.

McAlpine, D., 2003. Pygmy and Dwarf Sperm Whales (Kogia breviceps and K. sima) In: Perrin W. F., B. Würsig \& J. G. M. Thewissen (eds), Encyclopedia of Marine Mammal. Academic Press, San Diego, CA: 1007-1009.

Meckley, T. D., C. M. Wagner \& E. Gurarie, 2014. Coastal movements of migrating sea lamprey (Petromyzon marinus) in response to a partial pheromone added to river water: implications for management of invasive populations. Canadian Journal of Fisheries and Aquatic Sciences 71: 533-544.

Murauskas, J. G., A. M. Orlov \& K. A. Siwicke, 2013. Relationships between the abundance of Pacific lamprey in the Columbia River and their common hosts in the marine environment. Transactions of the American Fisheries Society 142: 143-155.

Nichols, O. C. \& P. K. Hamilton, 2004. Occurrence of the parasitic sea lamprey, Petromyzon marinus, on western North Atlantic right whales, Eubalaena glacialis. Environmental Biology of Fishes 71: 413-417. 
Nichols, O. C. \& U. T. Tscherter, 2011. Feeding of sea lampreys Petromyzon marinus on minke whales Balaenoptera acutorostrata in the St Lawrence Estuary. Journal of Fish Biology 78: 338-343.

Orlov, A. M., V. F. Savinykh \& D. V. Pelenev, 2008. Features of spatial distribution and size composition of Pacific lamprey Lampetra tridentata in the North Pacific. Russian Journal of Marine Biology 34: 276-287.

Orlov, A. M., R. K. Beamish, A. V. Vinnikov \& D. Pelenev, 2009. Feeding and prey of Pacific Lamprey in coastal waters of the western North Pacific. In: Haro, A., K. L. Smith, R. A. Rulifson, C. M. Moffitt, R. J. Klauda, M. J. Dadswell, R. A. Cunjak, J. E. Cooper, K. L. Beal \& T. S. Avery (eds) Challenges For Diadromous Fishes In A Dynamic Global Environment. American Fisheries Society Symposium 69. Bethesda, Maryland: 875-877.

Ólafsdóttir, D. \& A. P. Shinn, 2013. Epibiotic macrofauna on common minke whales, Balaenoptera acutorostrata Lacépède, 1804, in Icelandic waters. Parasites \& vectors 6: 105 .

Pauly, D., V. Christensen, J. Dalsgaard, R. Froese \& F. Torres Jr., 1998. Fishing Down Marine Food Webs. Science 279: 860-863.

Pereira, A. M., B. Jonsson, M. Johannsson, J. I. Robalo \& V. C. Almada, 2012. Icelandic lampreys (Petromyzon marinus): where do they come from?. Ichthyological research 59: 83-85.

Potter, C. \& F. W. H. Beamish, 1977. The freshwater biology of adult anadromous sea lampreys Petromyzon marinus. Journal of Zoology 181: 113-130. 
Powell, K., J. G. Trial, N. Dubé \& M. Opitz, 1999. External parasite infestation of searun Atlantic salmon (Salmo salar) during spawning migration in the Penobscot River, Maine. Northeastern Naturalist 6: 363-370.

Quintella, B. R., N. O. Andrade \& P. R. Almeida, 2003. Distribution, larval stage duration and growth of the sea lamprey ammocoetes, Petromyzon marinus L., in a highly modified river basin. Ecology of Freshwater Fish 12: 286-293.

Quintella, B. R., N. O. Andrade, A. Koed \& P. R. Almeida, 2004. Behavioural patterns of sea lampreys' spawning migration through difficult passage areas, studied by electromyogram telemetry. Journal of Fish Biology 65: 961-972.

Renaud, C. B., 2011. Lampreys of the world: an annotated and illustrated catalogue of lamprey species known to date. FAO Species Catalogue for Fisheries Purposes No. 5. Rome, FAO 2011.

Renaud, C. B., H. S. Gill \& I. C. Potter, 2009. Relationships between the diets and characteristics of the dentition, buccal glands and velar tentacles of the adults of the parasitic species of lamprey. Journal of Zoology 278: 231-242.

Rodríguez-Muñoz R., J. R. Waldman, C. Grunwald, N. K. Roy \& I. Wirgin, 2004. Absence of shared mitochondrial DNA haplotypes between sea lamprey from North American and Spanish rivers. Journal of Fish Biology 64: 783-787.

Samarra, F. I. P., A. Fennell, K. Aoki, V. B. Deeck \& P. J. O. Miller, 2012. Persistence of skin marks on killer whales (Orcinus orca) caused by the parasitic sea lamprey (Petromyzon marinus) in Iceland. Marine Mammal Science 28: 395401. 
Silva, S., M. J. Servia, R. Vieira-Lanero, S. Barca \& F. Cobo, 2013a. Life cycle of the sea lamprey Petromyzon marinus: duration of and growth in the marine life stage. Aquatic Biolology 18: 59-62.

Silva, S., M. J. Servia, R. Vieira-Lanero \& F. Cobo, 2013b. Downstream migration and hematophagous feeding of newly metamorphosed sea lampreys (Petromyzon marinus Linnaeus, 1758). Hydrobiologia 700: 277-286.

Silva, S., M. J. Servia, R. Vieira-Lanero, D. J. Nachón \& F. Cobo, 2013c. Haematophagous feeding of newly metamorphosed European sea lampreys Petromyzon marinus on strictly freshwater species. Journal of Fish Biology 82: 1739-1745.

Silva, S., R. Vieira-Lanero, J. Sánchez-Hernández, M. J. Servia \& F. Cobo, in press. Accidental introduction of anadromous sea lampreys (Petromyzon marinus Linnaeus, 1758) into a European reservoir. Limnetica

Spice, E. K., D. H. Goodman, S. B. Reid \& M. F. Docker, 2012. Neither philopatric nor panmictic: microsatellite and mtDNA evidence suggests lack of natal homing but limits to dispersal in Pacific lamprey. Molecular Ecology 21: 2916-2930.

Taverny, C. \& P. Elie, 2010. Les lamproies en Europe de l'Ouest: écophases, espèces et habitats. Quae, Versailles.

van Utrecht, W. L., 1959. Wounds and scars in the skin of the common porpoise Phocaena phocaena (L.). Mammalia 13: 100-122. 
Waldman, J. R., C. Grunwald, \& I. Wirgin, 2008. Sea lamprey Petromyzon marinus: an exception to the rule of homing in anadromous fishes. Biology Letters 4: 659662.

Wilkie, M. P., S. Turnbull, J. Bird, Y. S. Wang, J. F. Claude \& J. H. Youson, 2004. Lamprey parasitism of sharks and teleosts: high capacity urea excretion in an extant vertebrate relic. Comparative Biochemistry and Physiology 138A: 485492. 


\section{Tables}

Table 1 New records of host species of anadromous Petromyzon marinus during the haematophagous feeding phase. In bold host species described for the first time as part of the diet of P. marinus. For S. trutta (R): resident form. NWAO: North West Atlantic Ocean; NWIP: North West Iberian Peninsula; FB: French Brittany; MR: mark-recapture campaign; CF: commercial fishing; SF: sport fishing; UPT: upstream permanent trap; SCE: scientific expedition; STR: stranded individual

\begin{tabular}{|c|c|c|c|c|}
\hline Species & Location of capture & Method & Habitat & Date \\
\hline \multicolumn{5}{|l|}{ Chondrichthyes } \\
\hline Prionace glauca (Linnaeus, 1758) & NWAO $\left(42^{\circ} \mathrm{N} ; 45^{\circ} \mathrm{W}\right)$ & MR & Ocean & $27 / 04 / 2009$ \\
\hline Prionace glauca (Linnaeus, 1758) & NWAO $\left(42^{\circ} \mathrm{N} ; 45^{\circ} \mathrm{W}\right)$ & MR & Ocean & $05 / 07 / 2010$ \\
\hline Myliobatis aquila (Linnaeus, 1758) & Ría de Vigo, NWIP & $\mathrm{CF}$ & Ocean & June 2013 \\
\hline \multicolumn{5}{|l|}{ Osteichthyes } \\
\hline Belone belone (Linnaeus, 1761) & Cies Islands, NWIP & SF & Coast & $09 / 02 / 2008$ \\
\hline Alosa alosa (Linnaeus, 1758) & River Miño estuary, NWIP & $\mathrm{CF}$ & Estuary & $10 / 05 / 2011$ \\
\hline Alosa alosa (Linnaeus, 1758) & River Miño estuary, NWIP & $\mathrm{CF}$ & Estuary & $25 / 03 / 2014$ \\
\hline Alosa alosa (Linnaeus, 1758) ${ }^{\mathrm{c}}$ & Pont-Scorff, FB & UPT & Freshwater & $01 / 05 / 2010$ \\
\hline Abramis brama (Linnaeus, 1758) ${ }^{\text {b }}$ & Lough Derg, Ireland & SF & Freshwater & $2006-2012$ \\
\hline Rutilus rutilus (Linnaeus, 1758) ${ }^{\mathbf{b}}$ & Lough Derg, Ireland & $\mathrm{SF}$ & Freshwater & $2006-2012$ \\
\hline Esox lucius Linnaeus, $\mathbf{1 7 5 8}^{\mathrm{b}}$ & Lough Derg, Ireland & SF & Freshwater & 2006-2012 \\
\hline Merluccius merluccius (Linnaeus, 1758) & Portonovo, NWIP & SCE & Coast & $14 / 03 / 2007$ \\
\hline Merluccius merluccius (Linnaeus, 1758) & Portonovo, NWIP & SCE & Coast & $25 / 05 / 2005$ \\
\hline Liza ramada $(\text { Risso, } 1810)^{\mathrm{c}}$ & Saint-Nazaire Port, FB & $\mathrm{CF}$ & Estuary & April 2009 \\
\hline Anarhichas lupus Linnaeus, 1758 & NWAO $\left(47^{\circ} \mathrm{N} ; 47^{\circ} \mathrm{W}\right)$ & SCE & Ocean & $01 / 07 / 2013$ \\
\hline Trachurus trachurus Linnaeus, 1758 & Ría de Vigo, NWIP & $\mathrm{CF}$ & Coast & $01 / 05 / 2012$ \\
\hline Scomber scombrus Linnaeus, $1758^{c}$ & Bay of Vilaine, FB & $\mathrm{CF}$ & Coast & April 2009 \\
\hline Boops boops (Linnaeus, 1758) & Ría de Pontevedra, NWIP & $\mathrm{CF}$ & Coast & $04 / 10 / 2013$ \\
\hline Trichiurus lepturus Linnaeus, 1758 & Ancora, NWIP & $\mathrm{CF}$ & Coast & April 2012 \\
\hline Reinhardtius hippoglossoides (Walbaum, 1792) ${ }^{\mathbf{a}}$ & NWAO $\left(43^{\circ} \mathrm{N} ; 52^{\circ} \mathrm{W}\right)$ & SCE & Ocean & $01 / 07 / 2013$ \\
\hline Solea solea (Linnaeus, 1758) ${ }^{\mathrm{c}}$ & Bay of Vilaine, FB & $\mathrm{CF}$ & Coast & April 2009 \\
\hline Salmo salar Linnaeus, $1758^{\mathrm{c}}$ & Pont-Scorff, FB & UPT & Freshwater & May 2010 \\
\hline Salmo trutta Linnaeus, $1758(\mathrm{R})^{\mathrm{b}}$ & Lough Derg, Ireland & SF & Freshwater & 2006-2012 \\
\hline
\end{tabular}


Cetaceans

Balaenoptera acutorostrata Lacépède, 1804

$\begin{array}{cccc}\text { Camariñas, NWIP } & \text { STR } & \text { Coast } & 14 / 03 / 2005 \\ \text { Baiona Estuary, NWIP } & \text { STR } & \text { Coast } & 17 / 10 / 1998 \\ \text { Ribadesella, NWIP } & \text { STR } & \text { Coast } & 01 / 05 / 2013 \\ \text { Ribeira, NWIP } & \text { STR } & \text { Coast } & 26 / 11 / 2012\end{array}$

Grampus griseus (Cuvier, 1812)

Physeter macrocephalus Linnaeus, 1758

${ }^{a}$ Only non-pierced wounds were recorded (confirmation of active feeding was not accomplished)

Mesoplodon bidens (Sowerby, 1804)

${ }^{\mathrm{b}}$ Hume pers comm

${ }^{\mathrm{c}}$ Sabatié pers comm 
Table 2 List of host species described for the haematophagous stage of anadromous Petromyzon marinus. D: demersal; P-O: pelagic-oceanic; P-N: pelagic-neritic; B: bathypelagic; Po: potamodromous; Di: diadromous; O: oceanodromous; NM: non migratory

\begin{tabular}{|c|c|c|c|c|}
\hline Order & Family & Species & Ecology & Reference \\
\hline \multicolumn{5}{|l|}{ Chondrichthyes } \\
\hline Carcharhiniformes & Carcharhinidae & Carcharhinus obscurus (Lesueur, 1818) & $\mathrm{D}, \mathrm{O}$ & Jensen \& Schwartz (1994) \\
\hline Carcharhiniformes & Carcharhinidae & Carcharhinus plumbeus (Nardo, 1827) & $\mathrm{D}, \mathrm{O}$ & Jensen \& Schwartz (1994) \\
\hline Carcharhiniformes & Carcharhinidae & Galeocerdo cuvier (Péron and Lesueur, 1822) & $\mathrm{D}, \mathrm{O}$ & Jensen et al. (1998) \\
\hline Carcharhiniformes & Carcharhinidae & Prionace glauca (Linnaeus, 1758) & $\mathrm{P}-\mathrm{O}, \mathrm{O}$ & This paper \\
\hline Lamniformes & Cetorhinidae & Cetorhinus maximus (Gunnerus, 1765) & $\mathrm{P}-\mathrm{O}, \mathrm{O}$ & $\begin{array}{l}\text { Beamish (1980); } \\
\text { Wilkie et al. (2004) }\end{array}$ \\
\hline Myliobatiformes & Myliobatidae & Myliobatis aquila (Linnaeus, 1758) & $\mathrm{D}, \mathrm{O}$ & This paper \\
\hline Squaliformes & Somniosidae & $\begin{array}{l}\text { Somniosus microcephalus } \\
\text { (Bloch and Schneider, 1801) }^{\mathrm{a}}\end{array}$ & $\mathrm{D}, \mathrm{O}$ & Gallant et al. (2006) \\
\hline \multicolumn{5}{|l|}{ Osteichthyes } \\
\hline Acipenseriformes & Acipenseridae & Acipenser oxyrinchus Mitchill, 1815 & $\mathrm{D}, \mathrm{Di}$ & Renaud (2011) \\
\hline Acipenseriformes & Acipenseridae & Acipenser sturio Linnaeus, 1758 & $\mathrm{D}, \mathrm{Di}$ & Hardisty (1986) \\
\hline Beloniformes & Belonidae & Belone belone (Linnaeus, 1761) & $\mathrm{P}-\mathrm{O}, \mathrm{O}$ & This paper \\
\hline Clupeiformes & Clupeidae & Alosa aestivalis (Mitchill, 1814) & P-N, Di & Beamish (1980) \\
\hline Clupeiformes & Clupeidae & Alosa alosa (Linnaeus, 1758) & P-N, Di & This paper \\
\hline Clupeiformes & Clupeidae & Alosa fallax (Lacépède, 1803) & P-N, Di & Silva et al. (2013b) \\
\hline Clupeiformes & Clupeidae & Alosa pseudoharengus (Wilson, 1811) & P-N, Di & Beamish (1980) \\
\hline Clupeiformes & Clupeidae & Alosa sapidissima (Wilson, 1811) & P-N, Di & Beamish (1980) \\
\hline Clupeiformes & Clupeidae & Brevoortia tyrannus (Latrobe, 1802) & $\mathrm{P}-\mathrm{N}, \mathrm{O}$ & Mansuetti (1962) \\
\hline Clupeiformes & Clupeidae & Clupea harengus Linnaeus, 1758 & $\mathrm{D}, \mathrm{O}$ & Farmer (1980) \\
\hline Cypriniformes & Catostomidae & Catostomus commersonii (Lacepède, 1803) & $\mathrm{D}, \mathrm{Di}$ & Potter \& Beamish (1977) \\
\hline Cypriniformes & Cyprinidae & Abramis brama (Linnaeus, 1758) & $\mathrm{D}, \mathrm{Po}$ & Hume pers comm \\
\hline Cypriniformes & Cyprinidae & Luciobarbus bocagei (Steindachner, 1864) ${ }^{\mathrm{a}}$ & $\mathrm{D}, \mathrm{Po}$ & Araújo et al. (2013a) \\
\hline Cypriniformes & Cyprinidae & Pseudochondrostoma duriense (Coelho, 1985) & $\mathrm{D}, \mathrm{Po}$ & Silva et al. (2013c) \\
\hline Cypriniformes & Cyprinidae & Rutilus rutilus (Linnaeus, 1758) & $\mathrm{D}, \mathrm{Po}$ & Hume pers comm \\
\hline Esociformes & Esocidae & Esox lucius Linnaeus, 1758 & D, Po & Hume pers comm \\
\hline Gadiformes & Gadidae & Gadus morhua Linnaeus, 1758 & $\mathrm{D}, \mathrm{O}$ & Beamish (1980) \\
\hline Gadiformes & Gadidae & Melanogrammus aeglefinus (Linnaeus, 1758) & $\mathrm{D}, \mathrm{O}$ & Beamish (1980) \\
\hline Gadiformes & Gadidae & Pollachius virens (Linnaeus, 1758) & $\mathrm{D}, \mathrm{O}$ & Beamish (1980) \\
\hline Gadiformes & Phycidae & Urophycis chuss (Walbaum, 1792) & $\mathrm{D}, \mathrm{O}$ & Farmer (1980) \\
\hline
\end{tabular}




\begin{tabular}{|c|c|c|c|c|}
\hline Gadiformes & Merlucciidae & Merluccius merluccius (Linnaeus, 1758) & $\mathrm{D}, \mathrm{O}$ & This paper \\
\hline Mugiliformes & Mugilidae & Liza aurata (Risso, 1810) & P-N, Di & Silva et al. (2013b) \\
\hline Mugiliformes & Mugilidae & Liza ramada (Risso, 1810$)$ & P-N, Di & Sabatié pers comm \\
\hline Perciformes & Anarhichadidae & Anarhichas lupus Linnaeus, 1758 & $\mathrm{D}, \mathrm{O}$ & This paper \\
\hline Perciformes & Carangidae & Trachurus trachurus (Linnaeus, 1758) & $\mathrm{P}-\mathrm{N}, \mathrm{O}$ & This paper \\
\hline Perciformes & Moronidae & Dicentrarchus labrax (Linnaeus, 1758) & $\mathrm{D}, \mathrm{Di}$ & Taverny \& Elie (2010) \\
\hline Perciformes & Moronidae & Morone saxatilis (Walbaum, 1792) & $\mathrm{D}, \mathrm{Di}$ & Beamish (1980) \\
\hline Perciformes & Pomatomidae & Pomatomus saltatrix (Linnaeus, 1766) & $\mathrm{P}-\mathrm{O}, \mathrm{O}$ & Beamish (1980) \\
\hline Perciformes & Sciaenidae & Cynoscion regalis (Bloch and Schneider, 1801) & $\mathrm{D}, \mathrm{O}$ & Beamish (1980) \\
\hline Perciformes & Scombridae & Scomber scombrus Linnaeus, 1758 & $\mathrm{P}-\mathrm{N}, \mathrm{O}$ & $\begin{array}{l}\text { Farmer (1980); } \\
\text { Sabatié pers comm }\end{array}$ \\
\hline Perciformes & Scombridae & Thunnus thynnus (Linnaeus, 1758) & $\mathrm{P}-\mathrm{O}, \mathrm{O}$ & Halliday (1991) \\
\hline Perciformes & Sparidae & Boops boops (Linnaeus, 1758) & $\mathrm{D}, \mathrm{O}$ & This paper \\
\hline Perciformes & Trichiuridae & Trichiurus lepturus Linnaeus, 1758 & $\mathrm{D}, \mathrm{Di}$ & This paper \\
\hline Perciformes & Xiphiidae & Xiphias gladius Linnaeus, 1758 & $\mathrm{P}-\mathrm{O}, \mathrm{O}$ & Beamish (1980) \\
\hline Pleuronectiformes & Pleuronectidae & Reinhardtius hippoglossoides (Walbaum, 1792) & $\mathrm{D}, \mathrm{O}$ & This paper \\
\hline Pleuronectiformes & Soleidae & Solea solea (Linnaeus, 1758) & $\mathrm{D}, \mathrm{O}$ & Sabatié pers comm \\
\hline Salmoniformes & Salmonidae & Salmo salar Linnaeus, 1758 & $\mathrm{D}, \mathrm{Di}$ & $\begin{array}{l}\text { Beamish (1980); } \\
\text { Silva et al. (2013b) }\end{array}$ \\
\hline Salmoniformes & Salmonidae & Salmo trutta Linnaeus, $1758^{\mathrm{b}}$ & P-N, Di & $\begin{array}{l}\text { Silva et al. ( } 2013 \mathrm{~b} \text {, in press); } \\
\text { Hume pers comm }\end{array}$ \\
\hline Salmoniformes & Salmonidae & Salvelinus fontinalis (Mitchill, 1814) & $\mathrm{D}, \mathrm{Di}$ & Beamish (1980) \\
\hline Scorpaeniformes & Sebastidae & Sebastes mentella Travin, 1951 & $\mathrm{~B}, \mathrm{O}$ & This paper \\
\hline \multicolumn{5}{|l|}{ Cetaceans } \\
\hline Cetartiodactyla & Balaenidae & Eubalaena glacialis (Müller, 1776) ${ }^{\mathrm{a}}$ & $\mathrm{P}-\mathrm{O}, \mathrm{O}$ & Nichols \& Hamilton (2004) \\
\hline Cetartiodactyla & Balaenopteridae & Balaenoptera acutorostrata Lacépède, 1804 & $\mathrm{P}-\mathrm{O}, \mathrm{O}$ & $\begin{array}{l}\text { Nichols \& Tscherter (2011); } \\
\text { this paper }\end{array}$ \\
\hline Cetartiodactyla & Balaenopteridae & Balaenoptera borealis Lesson, 1828 & $\mathrm{P}-\mathrm{O}, \mathrm{O}$ & Japha (1910) \\
\hline Cetartiodactyla & Balaenopteridae & Balaenoptera physalus (Linnaeus, 1758) & $\mathrm{P}-\mathrm{O}, \mathrm{O}$ & Japha (1910) \\
\hline Cetartiodactyla & Delphinidae & Grampus griseus (Cuvier, 1812) & $\mathrm{P}-\mathrm{O}, \mathrm{O}$ & This paper \\
\hline Cetartiodactyla & Delphinidae & Orcinus orca (Linnaeus, 1758) ${ }^{\mathrm{a}}$ & $\mathrm{P}-\mathrm{O}, \mathrm{O}$ & Samarra et al. (2012) \\
\hline Cetartiodactyla & Phocoenidae & Phocoena phocoena (Linnaeus, 1758) & $\mathrm{P}-\mathrm{O}, \mathrm{O}$ & van Utrecht (1959) \\
\hline Cetartiodactyla & Physeteridae & Kogia breviceps (Blainville, 1838) & $\mathrm{P}-\mathrm{O}, \mathrm{NM}$ & McAlpine (2003) \\
\hline Cetartiodactyla & Physeteridae & Kogia sima (Owen, 1866) & $\mathrm{P}-\mathrm{O}, \mathrm{NM}$ & McAlpine (2003) \\
\hline Cetartiodactyla & Physeteridae & Physeter macrocephalus Linnaeus, 1758 & $\mathrm{P}-\mathrm{O}, \mathrm{O}$ & This paper \\
\hline Cetartiodactyla & Ziphidae & Mesoplodon bidens (Sowerby, 1804) & $\mathrm{P}-\mathrm{O}, \mathrm{NM}$ & This paper \\
\hline Cetartiodactyla & Ziphidae & Ziphius cavirostris Cuvier, 1823 & $\mathrm{P}-\mathrm{O}, \mathrm{NM}$ & Heyning (2003) \\
\hline
\end{tabular}

\footnotetext{
${ }^{a}$ Only non-pierced wounds were recorded (confirmation of active feeding was not accomplished)
}

${ }^{\mathrm{b}}$ Both resident and anadromous forms 
Table 3 Ecological classification of host species described for the haematophagous stage of anadromous Petromyzon marinus.

\begin{tabular}{|c|c|c|c|c|c|}
\hline Distribution range (migratory pattern) & $\mathbf{n}$ & $\%$ & Habitat in the water column & $\mathbf{n}$ & $\%$ \\
\hline Freshwater (potamodromous) & 4 & 7 & & & \\
\hline Freshwater (non-migratory) & 0 & 0 & Demersal & 26 & 48 \\
\hline Diadromous & 16 & 30 & Pelagic (neritic) & 11 & 20 \\
\hline Marine (oceanodromous) & 30 & 56 & Pelagic (oceanic) & 16 & 30 \\
\hline Marine (non-migratory) & 4 & 7 & Bathypelagic & 1 & 2 \\
\hline Total & 54 & 100 & Total & 54 & 100 \\
\hline \multirow[t]{2}{*}{ Trophic guild } & $\mathbf{n}$ & $\%$ & Conservation status (IUCN) & $\mathbf{n}$ & $\%$ \\
\hline & & & Critically endangered & 1 & 2 \\
\hline Carnivorous & 28 & 52 & Endangered & 3 & 6 \\
\hline Detritivorous & 1 & 2 & Vulnerable & 7 & 13 \\
\hline Grazers & 0 & 0 & Near threatened & 20 & 37 \\
\hline Omnivorous & 4 & 7 & Least concern & 18 & 33 \\
\hline Planktivorous & 21 & 39 & Not Evaluated and Deficient Data & 5 & 9 \\
\hline Total & 54 & 100 & Total & 54 & 100 \\
\hline
\end{tabular}




\section{Figure captions}

Fig. 1 Location of areas where species wounded by Petromyzon marinus were found. A: Coast and estuaries of NW Iberian Peninsula (commercial fishing, sport fishing and strandings); B: Rivers, estuaries and coast of French Brittany (R. Sabatié pers comm); C: Lough Derg, Ireland (J. B. Hume pers comm); D: North West Atlantic Ocean (markrecapture campaign); E: North West Atlantic Ocean (scientific expedition)

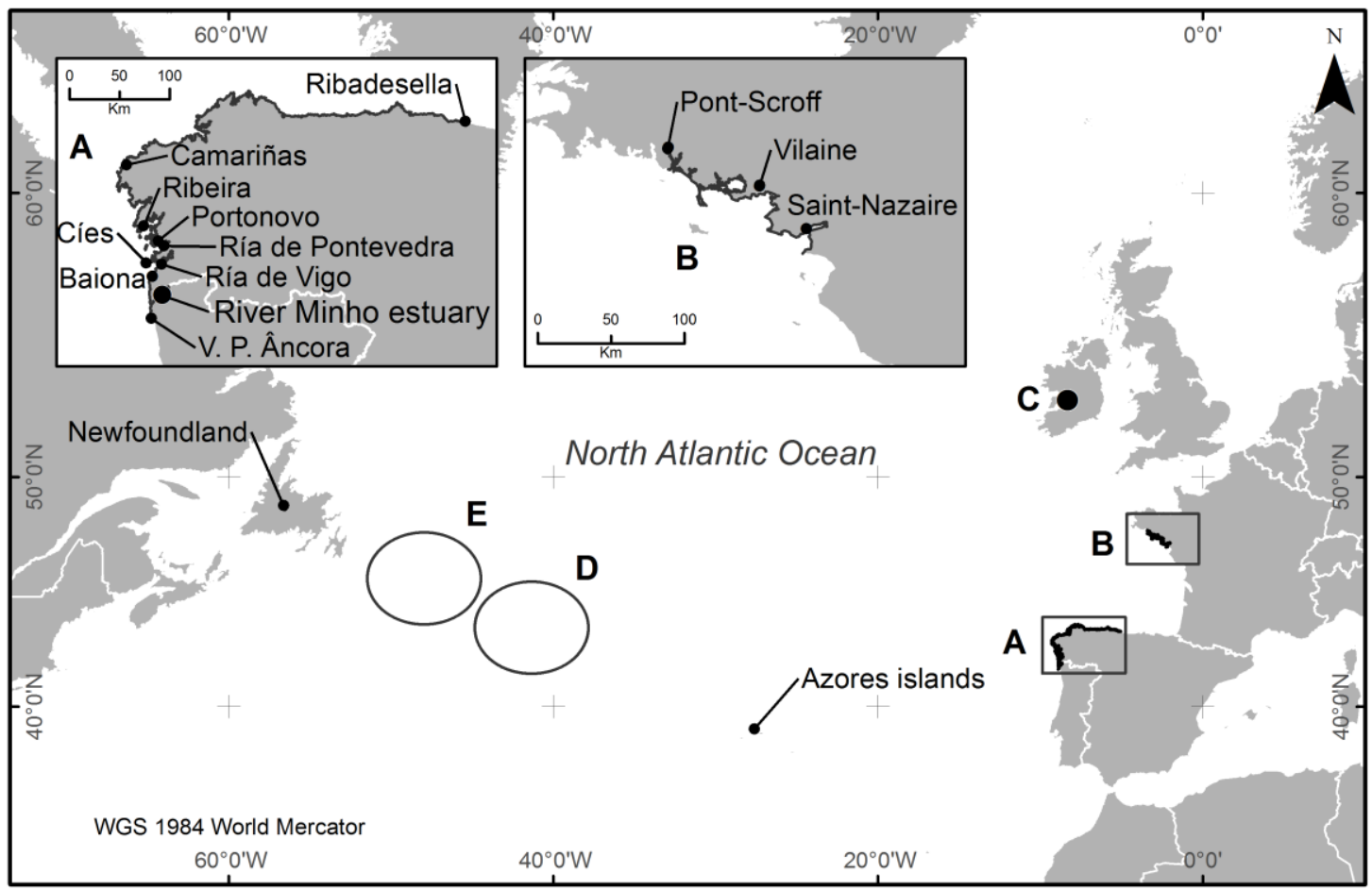


Fig. 2 Alosa alosa (a), Liza ramada (b), Scomber scombrus (c), Trachurus trachurus (d), Merluccius merluccius (e) and Sebates metella (f) attacked by Petromyzon marinus
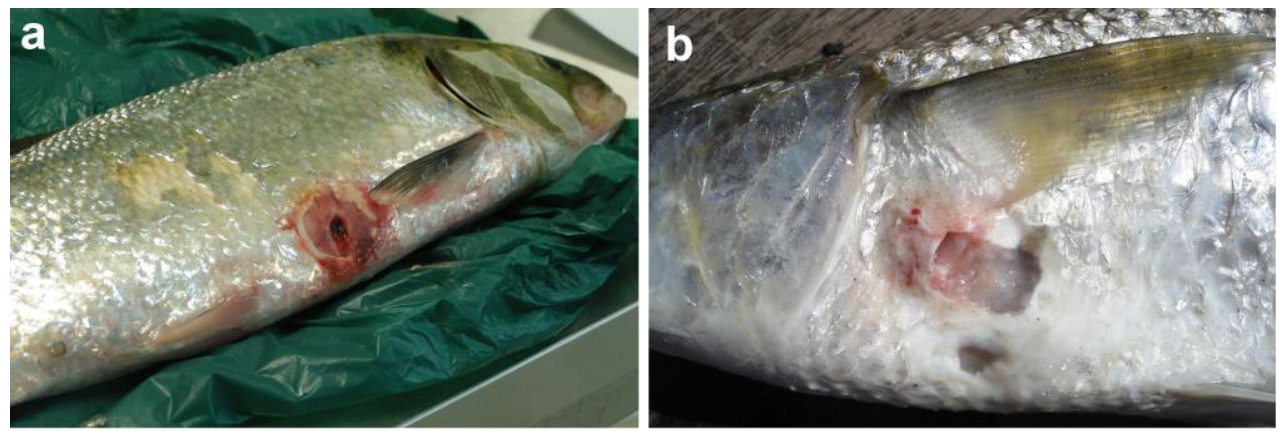

C

d
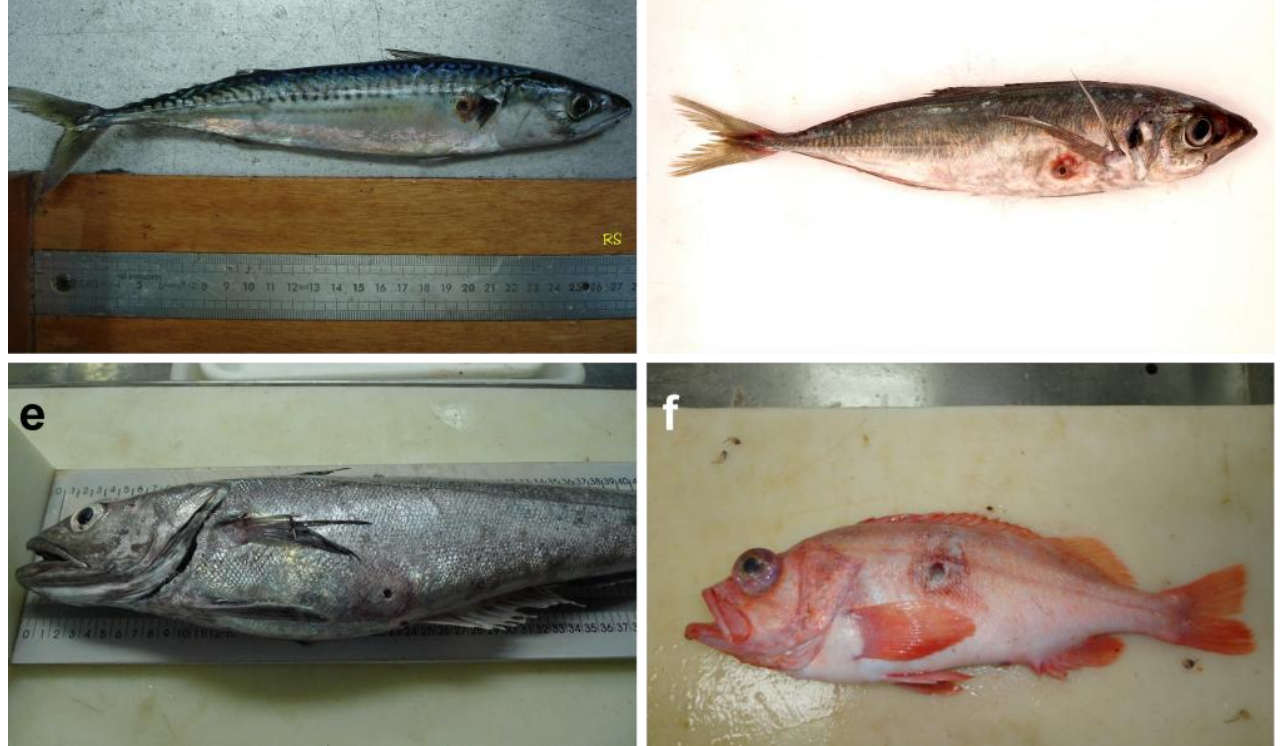
Fig. 3 Pierced (a) and non-pierced (b) wounds caused by Petromyzon marinus on Mesoplodon bidens. Pierced (c) and non-pierced (d) wounds caused by P. marinus on Balaenoptera acutorostrata
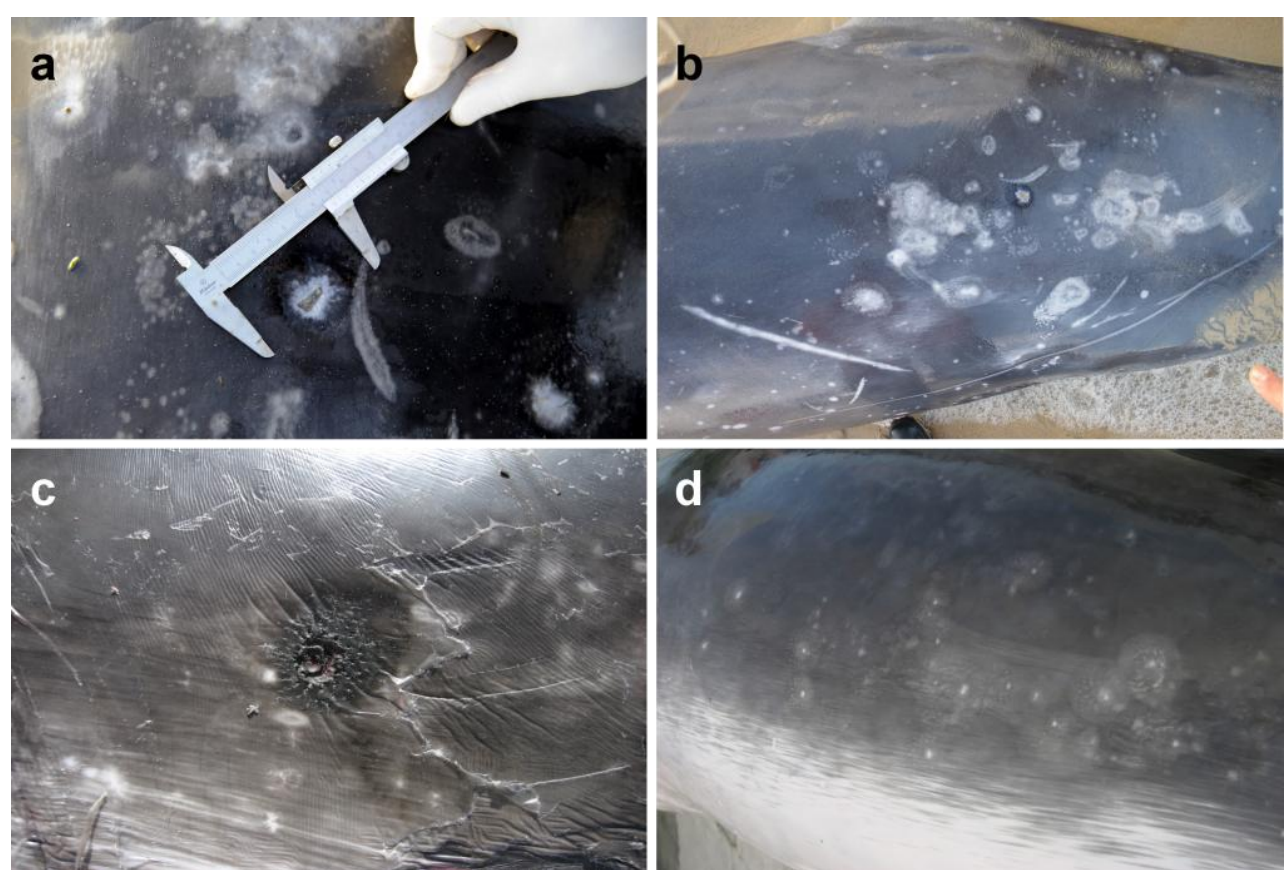
Online resource 1 First evidence of Petromyzon marinus feeding on Prionace glauca 